Tourism Research Journal

E-ISSN: 2598-9839

2018, Vol. 2 No. 1

\title{
The Influence of Accessibility And Facilities on Visitor Satisfaction in Mangrove Forests Pantai Indah Kapuk
}

\author{
Thalia Septiani $^{*}$, Tri Djoko Sulistio ${ }^{2}$ \\ 1,2Sekolah Tinggi Pariwisata Trisakti \\ *thaliaseptianii@gmail.com
}

\begin{abstract}
Green nature in particular in Angke Kapuk Nature Park is a natural conservation area that is used for natural tourism activities and centered on the development of ecotourism. This mangrove forest nature park is a natural conservation area dominated by mangrove vegetation. Nature Park is very influenced by several things, especially accessibility and facilities provided. This research purposes to determine the effect of accessibility and existing facilities in Taman Wisata Alam to visitor satisfaction. The method of analysis used in this research is descriptive and quantitative method of regression. This method is do so that it can give conclusion and picture how accessibility and facility can influence visitor satisfaction. Based on the results of research on the Influence of Accessibility and Facilities to the Mangrove Forest Visitor Satisfaction in Pantai Indah Kapuk, it can be seen that the level of influence given variable X1 (Accessibility) to variable Y (Visitor Satisfaction) is $23.8 \%$ and the level of influence given variable X2 (Facility) to variable Y (Visitor Satisfaction) is equal to $76,3 \%$. Therefore, managers should pay more attention to aspects that affect customer satisfaction
\end{abstract}

Keywords: accessibility, tourist facilities, visitor satisfaction, ecotourism

Tourism Research Journal, Volume 2 (1), 2018 


\section{A. Introduction}

Indonesia as one of the countries that have a variety of biodiversity and supported by its stunning natural beauty, and has a diverse culture, has a great opportunity to rely on natural tourism (ecotourism) as a source of foreign exchange. Basically ecotourism is a fusion of interests growing from environmental, economic, and social concerns. Meanwhile, according to the language dictionary, ecotourism is a form of tourism activities that pay attention or in line with conservation activities.

Indonesia is a rich country, we must be proud of our country. We have the world's largest mangrove forest, exotic coral reefs, seaweed spread over the beach, an invaluable source of fisheries. Indonesia is a country with the largest mangrove forest in the world with the world's largest biodiversity and the most varied structures in the world. Green open space in particular is Angke Kapuk Nature Park is a natural conservation area that is used for natural tourism activities and centered on the development of Eco-tourism. This nature park is a natural conservation area dominated by mangrove vegetation. Tourism cannot be separated from the accessibility needed. Travelers need adequate accessibility to get to the tourist attractions. Accessibility consists of access to information where facilities should be easy to find and easy to reach, must have access to road conditions that can be passed and get to the place of tourism and there must be the end of a place of travel. In addition, tourist attractions should provide some facilities that can be used for tourists to travel throughout the forest location.

Comfort and safety is also a factor where the facilities provided are sufficient or in accordance with the needs of the visitors. In this case how much influence the accessibility and facilities for the satisfaction of tourists in the mangrove forest should be in carefully. based on the background, the authors conduct research by raising the title "The Influence of Accessibility and Facilities on Visitor Satisfaction in Mangrove Forest Pantai Indah Kapuk".

\section{B. Literature Review}

\section{Accessibility}

Tourism accessibility is intended as "all facilities that provide convenience to tourists to reach a destination or tourist destination related". Factors that are important and related to accessibility aspects of tourism include directions (road conditions), time required (travel time), travel distance, frequency of transportation to tourist sites and other devices (Suna 2013). Tamin (2000) says the accessibility indicator can simply be expressed by distance. If a place is adjacent to another place, it is said the accessibility between the two places is high. Conversely, if the distance of accessibility between the two is low. In addition to distance and time, costs are also some accessibility indicators.

The link between Spatial Planning and Transportation says spatial policy is closely related to transportation policy. Between the activity space and transportation occurs a so-called cycle of transportation space usage. When

Tourism Research Journal, Volume 2 (1), 2018 
transportation access to an activity room is improved, the activity space becomes more attractive, and usually becomes more developed. With the development of the space, also increased the need for transportation. This increase then causes overload on the transport, which must be addressed, and the cycle will recur when accessibility is improved (Tamin, 2000).

\section{Facilities}

Tourist facilities are a means of support that can create a sense of fun accompanied by the ease and fulfillment of the needs of tourists in enjoying the tourism products on offer. The means consisting of several kinds of means of tourism, where one with another complement each other. In the tourism business attraction to make more tourists come, longer stay, spending more money in places visited, then these tools are very important role. To support it then in providing facilities also need a service that can provide convenience and comfort to tourists. The form of service facilities within a destination include accommodation, transportation in destinations, restaurants, sports facilities and activities, other facilities, and retail outlets (Yoeti, 2005).

Suwantoro (2000: 57) stated that tourism facilities consist of accommodation, restaurant, recreation and entertainment business, transportation and other facilities such as souvenir shop, ATM Center, parking temple and public toilet facilities. Accommodation is a means to provide lodging services that can be equipped with food and drink services and other services.

\section{Visitor Satisfaction}

Customer satisfaction is a feeling of immediate pleasure that customers feel when customers' expectations of a product are met or even exceed customer expectations. When a customer feels satisfied then the customer can re-buy again even the customer will share a happy experience to their relatives for the results that satisfy him after consuming the product. Aspects of customer satisfaction by Kotler (2002), namely:

a. Expectation

things that affect consumer satisfaction start at the stage before the purchase, that is when the consumer set up expectations about what will be received from the product.

b. Perfomance

During consumption activities, consumers feel the performance and benefits of the product are actually viewed from the dimension of consumer interest.

c. Comparism

After consuming, both expectations before purchase and perception of actual performance compared by consumers.

d. Confirmation or Disconfirmation

Affirmation of consumer expectations, whether pre-purchase expectations with purchasing perceptions are the same or not.

e. Discrepancy

Tourism Research Journal, Volume 2 (1), 2018 
If performance levels remain unequal, recognition of inequalities determines differences with each other. The negative confirmation that determines the actual performance is below the expectation level, the greater the consumer's discontent.

The relationship between accessibility and facilities will affect customer satisfaction. The relationship between customer satisfaction influenced by accessibility factor and facility will greatly affect the number of tourists who will visit. Therefore, if the expectations of visitors from tourist attractions are not appropriate will cause a decrease in the quality of the sights.

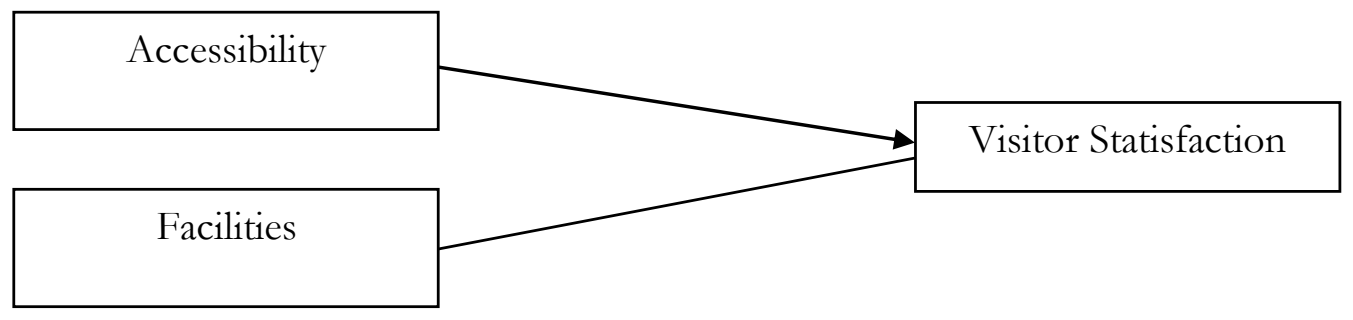

Figure 1. Research Model

\section{Research Methodology}

The technique or method used in this research is regression method. Based on the purpose of this study, the collected data will be processed by analyzing accessibility and facilities with the method. The analysis consists of accessibility and facility variables as independent variable and visitor satisfaction as dependent variable. The questionnaire that generated the data will be processed using SPSS software version 22 . The results of data processing from the questionnaire will be summarized or summarized so that it can provide conclusions and descriptions of how accessibility and facilities can affect visitor satisfaction.

The required sample size is obtained using Slovin formula. Then the number of respondents required in this study were 93 respondents.

Regression method is used to know the relationship between two variables so that can know the influence of accessibility and facility to visitor satisfaction. The unit of analysis should be blessed with the focus being studied ie in the form of objects, individuals, groups, regions and specific times according to the focus of his research. The result of the analysis unit is an individual assessment of the 17 - 30year old visitor who has visited Mangrove Forests Pantai Indah Kapuk and domiciled in Jabodetabek area (Jakarta, Bogor, Depok, Tangerang, Bekasi).

In this study data analysis used is by simple regression analysis and multiple regression analysis. Sugiyono (2010: 270) explains that simple regression analysis is based on the functional or causal relationship of one independent variable with one dependent variable. Multiple linear regression analysis is actually the same with simple linear regression analysis, only the independent variable more than one to know the influence of independent variable to dependent variable.

Tourism Research Journal, Volume 2 (1), 2018 


\section{Result}

\section{Simple Linear Regression Analysis of Accessibilty to Visitor Satisfaction}

To know the effect of variable $\mathrm{X} 1$ to variable $\mathrm{Y}$ used simple linear regression analysis. Here are the results of simple linear regression between accessibility variables (X1) to visitor satisfaction (Y).

Table 1. Results of Analysis of Variable Coefficient X1 to Variable Y

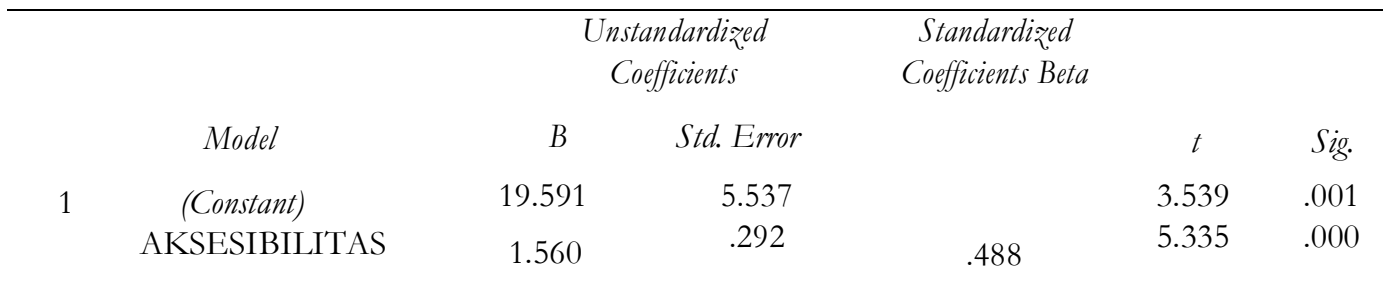

The table shows a simple linear regression equation between Accessibility (X1) variable to Visitor Satisfaction (Y) with the following equation:

$$
\mathrm{Y}=19.591+1.560 \mathrm{X}
$$

From the above equation, it can be explained that if Accessibility (X1) is constant or unchanged, then Visitor's Satisfaction (Y) created is 19,591 units. The value of Accessibility Regression coefficient (X1) is 1,560, it indicates that every increase of one respondent's appraisal unit to Accessibility (X1), it will increase Visitors Satisfaction of 1,560. If Accessibility is increasing, it will increase visitor satisfaction and vice versa if accessibility decrease will decrease visitor satisfaction.

$\mathrm{T}$ test is done to know the influence between the variable of accessibility (X1) to the variable of Visitor satisfaction (Y). Test $t$ is done by comparing the value of $t$ arithmetic with the value of $t$ table. If $t$ arithmetic $>t$ table then it can be stated that the variable Accessibility (X1) has an influence on the variable of Visitor Satisfaction (Y). The value of $t$ table at $\alpha=0.05$ is 1.990 . It shows that $t$ count $>t$ table $(5,335>1,990)$ so it can be stated that the Accessibility variable (X1) has partial effect on Visitor satisfaction (Y). Influence of accessibility consisting of the distance traveled, travel time, transportation and road conditions it was perceived by visitors that access through visitors into consideration so that it has participation in facilitating and determine the access of visitors in doing the tour so that the effect on visitor satisfaction

\section{Simple Linear Regression Analysis of Facilities to Visitor Satisfaction}

To know the effect of variable $\mathrm{X} 2$ to variable $\mathrm{Y}$ then done simple linear regression analysis. Here is the result of simple linear regression analysis between the Facilities (X2) variable to Visitor Satisfaction (Y). 
Table2: Results of Variable Coefficient Analysis of Variable X2

\begin{tabular}{|c|c|c|c|c|c|c|}
\hline & & $\begin{array}{l}\text { Unstar } \\
\text { Coeffic }\end{array}$ & & $\begin{array}{l}\text { Standardized } \\
\text { Coefficients }\end{array}$ & \multirow[b]{2}{*}{$t$} & \multirow[b]{2}{*}{ Sig. } \\
\hline & & $B$ & Std. Error & Beta & & \\
\hline \multirow[t]{2}{*}{1} & (Constant) & 4.925 & 2.612 & & 1.885 & .063 \\
\hline & FASILITAS & .904 & .053 & .873 & 17.102 & .000 \\
\hline
\end{tabular}

The table shows a simple linear regression equation between Facility variable (X2) to Visitor Satisfaction (Y) with equation as follows:

$$
\mathrm{Y}=4,925+0,904 \mathrm{X}
$$

From the above equation, it can be explained that if Facility (X2) is constant or unchanged, then Visitor Satisfaction (Y) created is 4.925 units. The value of regression coefficient of Facility (X2) of 0.904, this indicates that every increase of one unit of respondent appraisers to Facility (X2), it will increase Visitor satisfaction of 0.904 . If the Facility is increasing, it will increase the Visitor Satisfaction and vice versa if the facility decreases it will decrease Visitor's Satisfaction. T test is done to know the influence between Facility variable (X2) to variable of Visitor satisfaction (Y). Test $t$ is done by comparing the value of $t$ arithmetic with the value of $t$ table. If $t$ arithmetic $>t$ table then it can be stated that the Facility variable (X2) has an influence on the variable of Visitor Satisfaction (Y). The value of $t$ table at $\alpha=0.05$ is 1.990 . This indicates that $t$ arithmetic $>\mathrm{t}$ table $(17,102>1,990)$ so it can be stated that facility variable (X2) has partial influence to Visitor satisfaction (Y). Influence of Facilities as a means of support in the travel tour has participation because visitors need facilities ranging from scratch to the attractions such as parking lot to enjoy all the facilities provided to meet their needs in a travel tour that affect the visitor satisfaction.

\section{Multiple Linear Regression Analysis}

The table shows a simple linear regression equation between Accessibility variables (X1) and Facility (X2) on Visitor satisfaction (Y) with the following equation.

$\mathrm{Y}=4,447+0,047 \mathrm{X} 1+0,896 \mathrm{X} 2$

Tourism Research Journal, Volume 2 (1), 2018 


\section{Coefficients $^{\mathrm{a}}$}

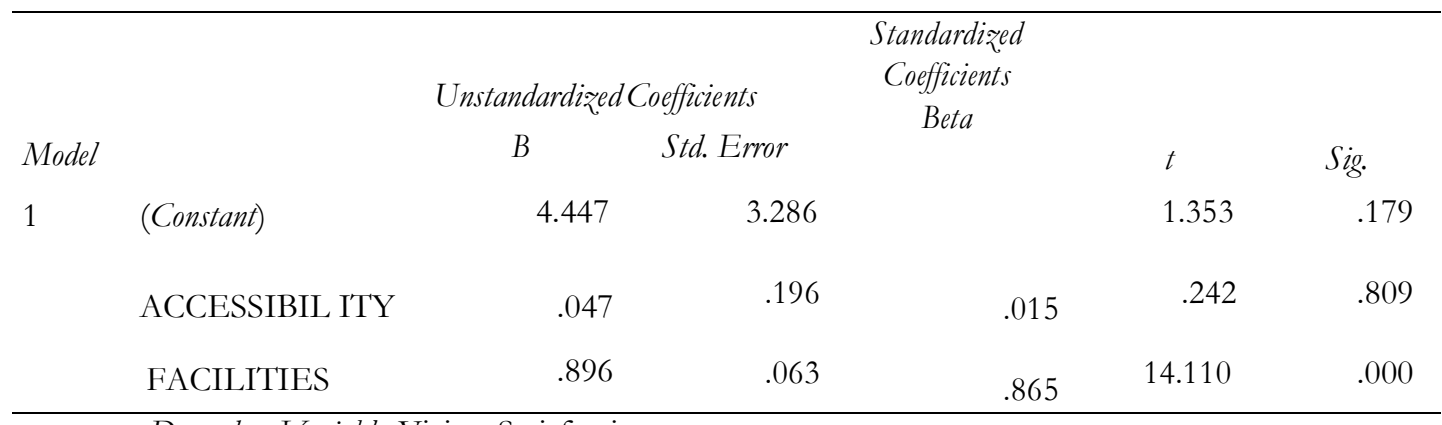

a. Dependent V ariable: Visitor Satisfaction

If $\mathrm{t}$ count $>\mathrm{t}$ table, then $\mathrm{H} 0$ is rejected. Based on the results of linear regression calculations $\mathrm{t}$ count $=0.242<\mathrm{t}$ table $=1.990$ then $\mathrm{H} 0$ is accepted and $\mathrm{H} 1$ is rejected. This means that there is no partially significant influence between Accessibility to Visitor Satisfaction.

If $\mathrm{t}$ count $>\mathrm{t}$ table, then $\mathrm{H} 0$ is rejected. Based on the results of linear regression calculations $t$ count $=14.110>\mathrm{t}$ table $=1.990$ then $\mathrm{H} 0$ is rejected. This means that there is a significant partial effect between Facilities on Visitor Satisfaction.

If Fcount $>$ Ftable, then $\mathrm{H} 0$ is rejected. Based on the results of multiple regression calculations Fcount $=144.753>$ Ftable $=2.07$, then $\mathrm{H} 0$ is rejected . There is a significant influence simultaneously between Accessibility (X1) and Facility (X2) on Visitor Satisfaction (Y).

\section{E. Discussion}

The implication of the results of the research is that after all the data has been collected and the results of the analysis are complete, firstly it is found that the respondents' assessment of Accessibility and Facilities to Visitor Satisfaction and respondent's answers varied. Furthermore, after the results of the questionnaire were analyzed using simple and multiple linear regression analysis, the results obtained were:

a. The research findings show that Accessibility (X1) has no significant effect on Visitor satisfaction (Y), with $\mathrm{t}$ arithmetic $=0,242<\mathrm{t}$ table $=$ 1,990. This shows that accessibility is not too influential on what visitors need so that the feeling of visitor satisfaction is not determined by matters relating to accessibility.

b. Research findings show that Facility (X2) has a significant effect on Visitor Satisfaction $(\mathrm{Y})$, with $\mathrm{t}$ arithmetic $=14.110<$ ttabel $=1.990$. This shows that the facilities provided by Htan Mangrove Pantai Indah Kapuk already available well and meet the sense of visitor satisfaction in travel.

c. Research findings show that Accessibility (X1) and Facilities (X2) together have a positive and significant influence on Visitor Satisfaction $(\mathrm{Y})$, with Fcount $=144.753>$ Ftable $=2.70$. This is increasingly evident

Tourism Research Journal, Volume 2 (1), 2018 
from the access and facilities provided by the manager to meet Visitor Satisfaction which consists of Expectation, Performance, Comparism, Confirmation/Disconfirmation, Discrepancy.

\section{F. Conclusion}

Based on the results of multiple linear regression test, the level of influence given by the two variables are X1 (Accessibility) and X2 (Facilities) variable Y (Visitor Satisfaction) is $76.3 \%$. The existence of a great influence in accessibility and facilities because with the access where road conditions, mileage, travel time as well as transportation and facilities provided is a consideration of visitors about the sights. Ease of access and fulfillment of visitor needs greatly affect the satisfaction created.

\section{REFERENCES}

Kotler, P. (2002). Manajemen Pemasaran (Edisi Millenium). Jakarta: Prehallindo.

Sugiyono. (2009). Quantitative, Qualitative and R \& D Research Methods. Bandung: Alfabeta.

Sunaryo, B. (2013). The Concept and Application Tourism Destination Development Policy in Indonesia. Yogyakarta : Gava Media.

Suwantoro, G. (2000). Basics of Tourism. Yogyakarta: Publisher Andi.

Tamin, O.Z. (2000). Transportation Planning and Modeling. Bandung: Publisher ITB.

Yoeti, O.A. (2005). Planning a Tourist Destination Marketing Strategy. Jakarta: PT Pradnya Paramita. 